\title{
EVOLUTION OF COSTS IN THE ACTIVITY OF A TRANSPORT COMPANY OPERATING WITHIN THE EUROPEAN UNION
}

\author{
${\text { Zbigniew } \text { Łukasik }^{1, a} \text {, Aldona Kusminska-Fijałkowska }}^{2, b}$, Jacek Kozyra ${ }^{3, c}$ \\ and Sylwia Olszańska ${ }^{4, d, *}$ \\ ${ }^{1}$ Faculty of Transport and Electrical Engineering, University of Technology and Humanities in \\ Radom, Malczewskiego 29, 26-600 Radom, Poland \\ ${ }^{2}$ Faculty of Transport and Electrical Engineering, University of Technology and Humanities in \\ Radom, Malczewskiego 29, 26-600 Radom, Poland \\ ${ }^{3}$ Faculty of Transport and Electrical Engineering, University of Technology and Humanities in \\ Radom, Malczewskiego 29, 26-600 Radom, Poland \\ ${ }^{4}$ Faculty of Transport and Electrical Engineering, University of Technology and Humanities in \\ Radom, Malczewskiego 29, 26-600 Radom, Poland \\ az.lukasik@uthrad.pl, ba.kusminska@uthrad.pl, cj.kozyra@uthrad.pl, ${ }^{\mathrm{d}} \mathrm{s}$. olszanska@uthrad.pl \\ *Corresponding author
}

Cite as: Lukasik, Z., Kusminska-Fijalkowska, A., Kozyra, J., Olszanska, S. (2017). Evolution of costs in the activity of a transport company operating within the European union, Ekonomicko-manazerske spektrum, 11(2), 53-63.

Available at: dx.doi.org/10.26552/ems.2017.2.53-63

\begin{abstract}
A transport company operating on the European market is primarily guided by the principle of rationality, i.e. it minimizes costs in order to increase financial results and strives to increase the efficiency of the services provided, while maintaining the current level of costs. What is more, competition forces transport companies to look for alternatives to optimize their operating costs. Thus, effective management in a transport company is conditioned by both strategic and tactical skills of managers. As a result, planning a business strategy should be preceded by a thorough analysis of the current economic condition of an enterprise, which also translates into determining the causes and factors that have a significant impact on the assessment and selection of the best enterprise management concepts. In addition, it is important to note that in the age of such great competition, every company is making every effort to achieve maximum turnover and, ultimately, the greatest revenue. As a result, managers are looking for ways to optimize costs so they do not have a negative impact on customer service levels. Thus, the cost optimization potential is when the optimization efforts are properly prepared and carried out, then the cost reduction can be significant. The research conducted by the authors illustrates the complexity of cost issues and exposes the critical aspects of the matters that form the decision base for the management of transport enterprises. The research methodology was implemented on the basis of financial statements for 2014-2015. This made it possible to classify the costs and changes existing in the analyzed transport company occurring under the impact of both internal and external factors.
\end{abstract}

Keywords: analysis, costs, transport

JEL Classification: L91, R40, R49, D61 


\section{Introduction}

Transport is one of the key sectors of the European economy based on knowledge, ecology. (Lukasik et al., 2017; Mostert et al., 2017) The EU is still increasing its investment in research and development of various forms of transport. (Bagloee et al., 2017; Kovacs, 2017; Nowacki et al., 2015) The effectiveness of the transport company depends primarily on changes occurring in its environment. (Petruccelli \& Carleo, 2017; Pregnolato et al., 2017; Łukasik et al., 2017) Therefore transport enterprises in the SME sector (Small Medium Enterprises) are a particularly important component of the national economy, since basically the whole of the EU economy depends on them. (Lukasik \& Kusminska-Fijałkowska, 2017; Grad et al., 2012; Lukasik et al., 2013) That is why the adaptability of these companies is particularly important that changing economic conditions, innovation in performance and strengthening competitiveness. (Krysiuk et al., 2014; Kusminska-Fijałkowska, 2017; Łukasik et al., 2016; Jacyna \& Pyza, 2015) Doing business in the examined European dimension requires proper cash management - so owning, acquiring, i.e. disposing of capital is crucial to your business. (Greene et al., 1997; Bąk, 2009; Bien, 2002; Friedrich et al., 2011; Hanssen et al., 2012; Monzon et al., 2008) Thus, the problem of transport costs in leading a transport enterprise is a very important element. (Kozlak, 2008; Twarog, 2003; Łukasik \& Olszanska, 2016; Maibach et al., 2008; Kovacs \& Guban, 2017; Łukasik et al., 2017; Takeshita \& Takayuki, 2010) From this it follows that the constant pursuit of broadening the profile and scope of business, as well as seeking optimal sources of development enabling it to expand, is for managers of transport companies an inherent development factor of an enterprise. (Hensher \& Button, 2005; Ozceylan, 2010; Nowakowski et al., 2016; Kibzun \& Krohmova, 2016; Nowacki et al., 2016; Kusminska-Fijalkowska \& Lukasik, 2011; KusminskaFijałkowska et al., 2017) Authors of this publication have performed research and analysis of the costs of the transport company operating on the area of the European Union. The have paid particular attention to general analysis and performed a thorough assessment of the functioning costs of the company.

\section{Methodology - overall costs analysis of the examined transport enterprise}

In table 1 and figure 1 the basic source data was placed regarding costs and basic indicators of their initial analysis, i.e. absolute change and dynamics index.

\begin{tabular}{|c|c|c|c|c|c|}
\hline \multirow[b]{2}{*}{$\begin{array}{l}\text { Serial } \\
\text { no. }\end{array}$} & \multirow[b]{2}{*}{ Parameters } & \multicolumn{2}{|l|}{ Year 2014} & \multicolumn{2}{|l|}{ Year 2015} \\
\hline & & $\begin{array}{l}\text { Realization } \\
\text { [thousand PLN] }\end{array}$ & $\begin{array}{l}\text { structure } \\
{[\%]}\end{array}$ & $\begin{array}{l}\text { realization } \\
\text { [thousand PLN] }\end{array}$ & $\begin{array}{l}\text { structure } \\
{[\%]}\end{array}$ \\
\hline 1 & Total revenue & 3815,4 & & 3691,3 & \\
\hline 2 & Total costs & 3517,3 & 100,0 & 3544,3 & 100,0 \\
\hline 3 & General costs & 552,2 & 15,7 & 476,0 & 13,4 \\
\hline 4 & Cost of sales of services & 2934,4 & 83,4 & 3056,6 & 86,2 \\
\hline 5 & Financial costs & 30,7 & 0,9 & 11,7 & 0,3 \\
\hline
\end{tabular}

Source: Own elaboration based on the conducted research 
Figure 1: Source data for cost analysis of the examined transport company

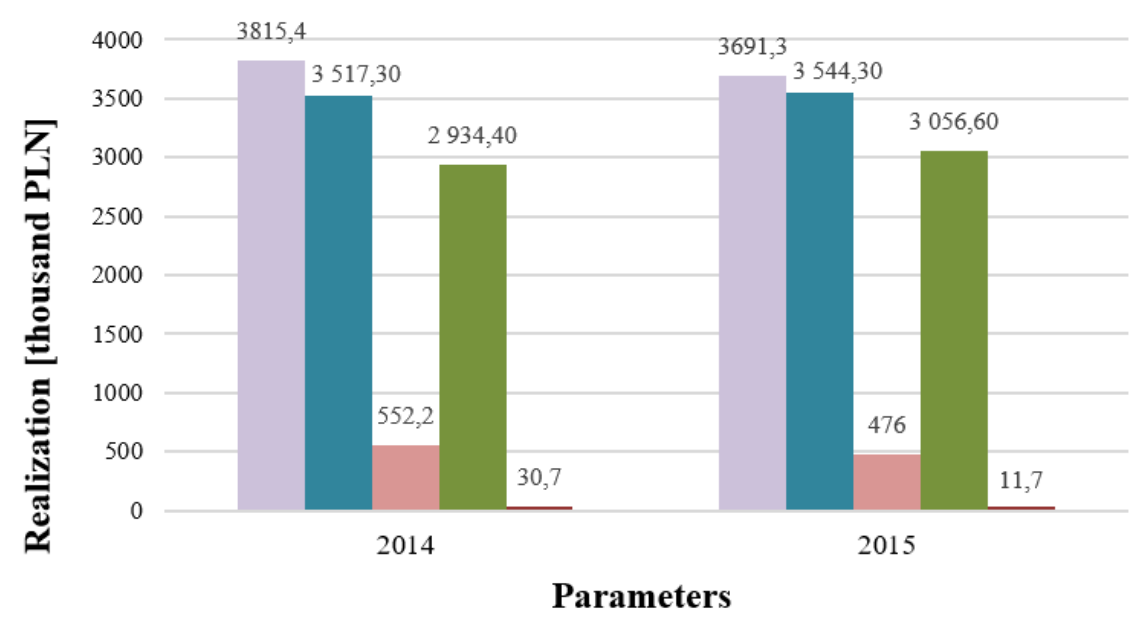

Source: Own elaboration based on the conducted research

Indicators of costs analysis are:

for total costs:

- absolute deviation (1):

$$
\begin{gathered}
\Delta K_{\text {total }}=K_{1}-K_{0}=3544,3[\text { thousand PLN }]-3517,3[\text { thousand } P L N]= \\
27,0[\text { thousand } P L N]
\end{gathered}
$$

- dynamics indicator (2):

for general costs:

$$
W_{\text {Ktotal }}=\frac{K_{1}}{K_{0}} \cdot 100 \%=\frac{3544,3[\text { thousand } P L N]}{3517,3[\text { thousand } P L N]} \cdot 100 \%=100,8 \%
$$

- absolute deviation (3):

$$
\begin{gathered}
\Delta K_{o g}=K_{1 o g}-K_{0 o g}=552,2[\text { thousand } P L N]-476,0[\text { thousand } P L N]= \\
-76,2[\text { thousand } P L N]
\end{gathered}
$$

- dynamics indicator (4):

$$
W_{\text {Ktotal }}=\frac{K_{10 g}}{K_{0 o g}} \cdot 100 \%=\frac{476,0[\text { thousand } P L N]}{552,2[\text { thousand } P L N]} \cdot 100 \%=86,2 \%
$$

for sales costs:

- absolute deviation (5):

$$
\begin{gathered}
\Delta K_{o g}=K_{1 o g}-K_{0 o g}=3056,6[\text { thousand PLN] }-2934,6[\text { thousand } P L N]= \\
+122,2[\text { thousand } P L N]
\end{gathered}
$$

- dynamics indicator (6):

$$
W_{\text {Ktotal }}=\frac{K_{1 \mathrm{og}}}{K_{0 \mathrm{og}}} \cdot 100 \%=\frac{3056,6[\text { thousand } P L N]}{2934,6[\text { thousand } P L N]} \cdot 100 \%=104,2 \%
$$

for financial costs:

- absolute deviation (7):

$$
\begin{aligned}
\Delta K_{\text {og }}=K_{1 \text { fin }}-K_{0 \text { fin }}= & 11,7[\text { thousand } P L N]-30,7[\text { thousand } P L N]= \\
-19,0[\text { thousand } P L N] & \text { (7) }
\end{aligned}
$$

- dynamics indicator (8):

$$
W_{\text {Ktotal }}=\frac{K_{1 \text { fin }}}{K_{0 \text { fin }}} \cdot 100 \%=\frac{11,7[\text { thousand } P L N]}{30,7[\text { thousand } P L N]} \cdot 100 \%=38,1 \%
$$


Table 2: Summary of the results of the analysis of the overall costs of the surveyed transport company

\begin{tabular}{|c|c|c|c|c|c|}
\hline \multirow{2}{*}{$\begin{array}{l}\text { Serial } \\
\text { no. }\end{array}$} & \multirow{2}{*}{ Parameters } & Year 2014 & Year 2015 & \multirow{2}{*}{$\begin{array}{l}\text { Absolute } \\
\text { deviation }\end{array}$} & \multirow{2}{*}{$\begin{array}{l}\text { Dynamics } \\
\text { indicator [\%] }\end{array}$} \\
\hline & & Realization & Realization & & \\
\hline 1 & Revenue from sales of services & 3815,4 & 3691,3 & $-124,1$ & 96,7 \\
\hline 2 & Costs in total & 3517,3 & 3544,3 & 27,0 & 100,8 \\
\hline 3 & General costs & 552,2 & 476,0 & $-76,2$ & 86,2 \\
\hline 4 & Selling costs & 2934,4 & 3056,6 & 122,2 & 104,2 \\
\hline 5 & Financial costs & 30,7 & 11,7 & $-19,0$ & 38,1 \\
\hline
\end{tabular}

Source: Own elaboration based on the conducted research

Figure 2: Percentage structure of the costs of the surveyed transport company

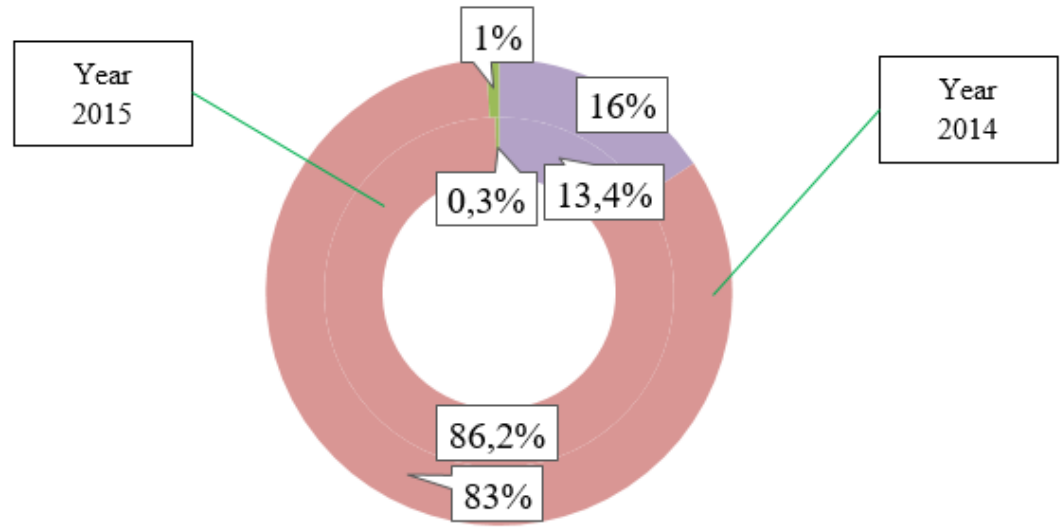

Source: Own elaboration based on the conducted research

\section{Results and discussion:}

1. The largest item of costs is the sales cost of transport services, accounting for $83.4 \%$ of the total costs of the base period and $86.2 \%$ of the total costs of the period considered (table 2, figure 2). Dominance of base operating costs over other costs should be considered normal and increasing their share - a favorable trend. This means that the "burden" of base business costs with other costs decreases,

2. Significant changes in cost structure have occurred - increasing the sales costs of services and, at the same time, reducing general and financial costs, which should be interpreted as the result of measures aimed at rationalizing the remaining costs.

3. In absolute figures, the costs in the comparable periods increased by 27 [thousand PLN] which means their increase by $0.8 \%$, and therefore relatively insignificant. It was only possible to obtain such an indicator by actively reducing other costs,

4. General costs decreased by 76.2 [thousand PLN], so by $13.8 \%$, which should be considered as a significant and beneficial difference,

5. Costs of sales of transport services increased by 122.2 [thousand PLN], and in relative numbers by $4.2 \%$, which gives a clear indication of the overall cost dynamics,

6. Financial expenses decreased by 19 [thousand PLN], so as high as $69.1 \%$ compared to the base period,

7. Thanks to the savings obtained on general and financial expenses, the overall costs dynamics has been significantly reduced, which is a positive phenomenon. However, this type of operation has limited capacity and in the next year, obtaining further savings in these areas may be more difficult. 
Important additional information will be provided by indicators of relative deviation that amount to:

in terms of total costs (thousand PLN) (9):

$$
\begin{gathered}
\Delta K_{t c}=3544,1[\text { thousand } P L N]-3517,3[\text { thousand PLN] }] \cdot \frac{3691,3[\text { thousand } P L N]}{3815,4[\text { thousand } P L N]}= \\
141,4[\text { thousand PLN] }
\end{gathered}
$$

in relation to the cost of selling services (10):

$$
\begin{array}{r}
\Delta K_{C S S}=2934,4[\text { thousand } P L N]-3056,6[\text { thousand } P L N] \cdot \frac{3691,3[\text { thousand } P L N]}{3815,4[\text { thousand } P L N]}= \\
217,6[\text { thousand PLN] }
\end{array}
$$

in relation to general costs (11):

$$
\begin{array}{r}
\Delta K_{g c}=475,9[\text { thousand } P L N]-552,2\left[\text { thousand PLN] } \cdot \frac{3691,3[\text { thousand } P L N]}{3815,4[\text { thousand } P L N]}=\right. \\
-58,2[\text { thousand PLN] }
\end{array}
$$

in relation to financial costs (12):

$$
\begin{array}{r}
\Delta K_{f c}=11,7\left[\text { thousand PLN] }-30,7\left[\text { thousand PLN] } \cdot \frac{3691,3[\text { thousand } P L N]}{3815,4[\text { thousand } P L N]}=\right.\right. \\
-18,0[\text { thousand PLN] }
\end{array}
$$

\section{Results and discussion:}

1. The relative deviation of total costs is as high as 141.4 [thousand PLN], so it is definitely higher than the absolute deviation of 27.0 [thousand PLN], which is a result of faster growth of total costs other than revenues. There is an unfavorable tendency to accelerate the pace of cost growth relative to the dynamics of revenue,

2. Due to the dominance of the costs of sales of services in the total cost structure, the relative costs of sales variance has reached a value of 217.6 [thousand PLN], which is also higher than the absolute deviation rate of 122.2 [thousand PLN]. Just as before, this proves the acceleration of cost growth,

3. The relative deviations of the remaining and financial costs are less than their absolute deviations, which results from their relatively small share of total costs.

\section{Results and Discussion - detailed analysis of the costs of the examined transport company}

Detailed costs analysis should be linked to the costs classification used in the company. (Bachmann et al., 2016; Yanxuan et al., 2016; Umberto, 2015) Most often, in enterprises, and especially in industry ones, the following costs sections are used:

1. generic, which allows to distinguish basic types of costs; consumption of materials, fuels and energy, foreign services, depreciation of fixed assets and others,

2. calculation that divides direct costs connected with the product and indirect ones that are shaped by the size of the potential and the overall size of the business,

3. division of variable and fixed costs from the point of view of responding to changes in production size (or other activity),

4. by source of costs. (Leszczynski \& Skowronek-Mielczarek, 2001)

\section{Results and discussion:}

1. The largest share in operating costs of core business is the purchase of fuel and it slightly increases from $63.6 \%$ to $63.8 \%$,

2. In second place in terms of share in operating costs of core business are salaries, which in the base period accounted for $9.3 \%$ and increased to $10.4 \%$, which is clearly faster than the cost of purchasing fuel, 
3. In third place are leasing fees, which this time decreased from $9.9 \%$ to $9.5 \%$, so their share decreased,

4. The following remain approximately at the same level of significance (around 5\%) remain:

a) purchase of spare parts and oils with a $4.5 \%$ share in the base period and $5.1 \%$ during the period considered,

b) tolls with a share of $4.2 \%$ in the base period and $3.6 \%$ during the examined period.

5. The significance of other categories of operating costs of core activities does not exceed $2.5 \%$,

6. In the area of other operating expenses, the most important item is the purchase of tires, which accounted for $45.3 \%$ of the costs of this group in the base period and decreased to $42.0 \%$ during the period considered. This may be due to two phenomena: longer exploitation of a set of tires or the purchase of cheaper sets,

7. The second place in this category is occupied by workshop costs, with a share of $29.5 \%$ and increased to $31.4 \%$,

8. The share of financial costs in total costs is not significant. (Table 3)

Table 3: Source data for detailed analysis of the costs of the surveyed transport company in a generic arrangement

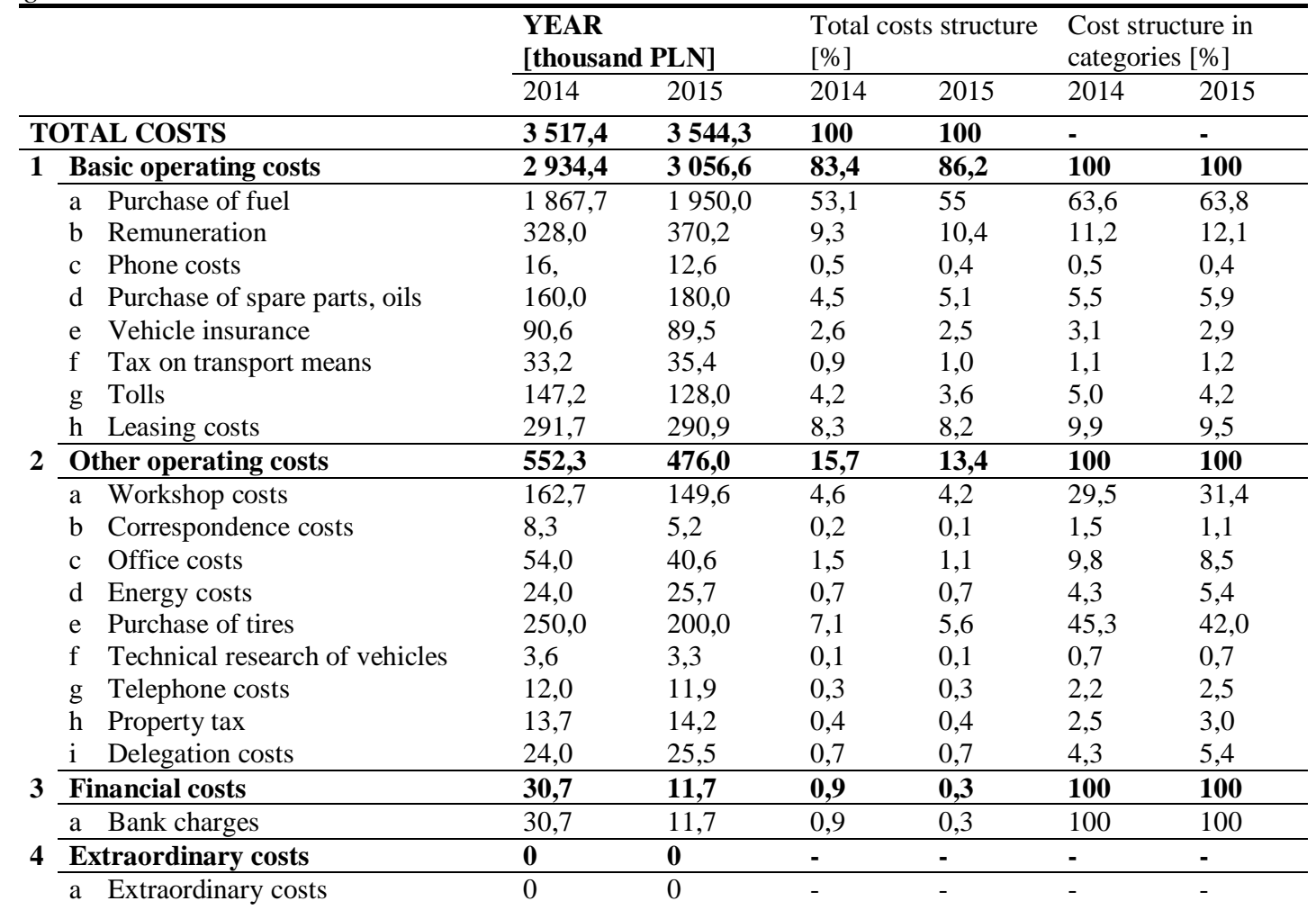

Source: Own elaboration based on the conducted research

Based on the above data, the absolute deviations and the dynamics of the most important costs components were calculated.

Operating costs of core business:

- absolute deviation (13):

$\Delta K_{\text {basic operational }}=K_{\text {basic operational(2015) }}-K_{\text {basic operational (2014) }}=$

3 056,6 [thousand PLN] - 2 934,4 [thousand PLN] = 122,2 [thousand PLN]

- dynamics indicator (14): 
$W_{K f u e l}=\frac{K_{\text {basic operational }(2015)}}{K_{\text {basic operational }}(2014)} \cdot 100 \%=\frac{3056,6[\text { thousand } P L N]}{2934,4[\text { thousand } P L N]} \cdot 100 \%=104,2 \%$

In the operating area of the core business:

fuel purchase costs:

- absolute deviation (15):

$$
\Delta K_{\text {fuel }}=K_{\text {fuel(2015) }}-K_{\text {fuel(2014) }}=1950,0[\text { thousand PLN] }-
$$

1867,7 [thousand PLN] $=82,3$ [thousand PLN]

- dynamics indicator (16):

$W_{K f u e l}=\frac{K_{\text {fuel }(2015)}}{K_{\text {fuel }(2014)}} \cdot 100 \%=\frac{1950,0[\text { thousand } P L N]}{1867,7[\text { thousand } P L N]} \cdot 100 \%=104,4 \%$

Salary costs:

- absolute deviation (17):

$$
\begin{aligned}
\Delta K_{\text {salary }}= & K_{\text {salary(2015) }}-K_{\text {salary (2014) }}=370,2[\text { thousand PLN] }- \\
& 328,0[\text { thousand } P L N]=42,2[\text { thousand } P L N]
\end{aligned}
$$

- dynamics indicator (18):

$$
W_{K f u e l}=\frac{K_{\text {salary }(2015)}}{K_{\text {salary }(2014)}} \cdot 100 \%=\frac{370,0[\text { thousand } P L N]}{328,0[\text { thousand } P L N]} \cdot 100 \%=112,9 \%
$$

Leasing costs:

- absolute deviation (19):

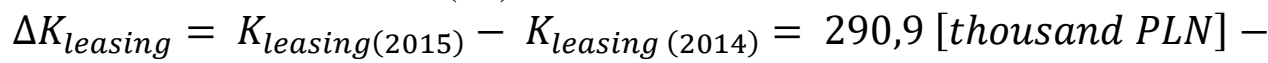

291,7 [thousand PLN] $=-0,8$ [thousand PLN]

- dynamics indicator (20):

$$
W_{\text {Kleasing }}=\frac{K_{\text {leasing }(2015)}}{K_{\text {leasing }(2014)}} \cdot 100 \%=\frac{290,9[\text { thousand } P L N]}{291,7[\text { thousand } P L N]} \cdot 100 \%=-0,8 \%
$$

costs of buying spare parts and oils:

- absolute deviation (21):

$\Delta K_{\text {spare parts }}=K_{\text {spare parts(2015) }}-K_{\text {spare parts(2014) }}=180,0[$ thousand PLN] 160,0 [thousand PLN] $=20,0$ [thousand PLN]

- dynamics indicator (22):

$W_{\text {Kspare parts }}=\frac{K_{\text {spare parts }(2015)}}{K_{\text {spare parts }(2014)}} \cdot 100 \%=\frac{180,0[\text { thousand } P L N]}{160,0[\text { thousand } P L N]} \cdot 100 \%=112,5 \%$

road toll charges:

- absolute deviation (23):

$\Delta K_{\text {road toll }}=K_{\text {road toll(2015) }}-K_{\text {road toll (2014) }}=128,0[$ thousand PLN] 147,2 [thousand PLN] $=-19,2$ [thousand PLN]

- dynamics indicator (24):

$W_{\text {road toll }}=\frac{K_{\text {road toll }(2015)}}{K_{\text {road toll }(2014)}} \cdot 100 \%=\frac{128,0[\text { thousand } P L N]}{147,2[\text { thousand } P L N]} \cdot 100 \%=87,0 \%$

\section{Results and discussion:}

1. Increase in fuel costs amounted to $4.4 \%$ (in absolute figures +82.3 thousand PLN), which may be justified in fuel price increases. However, for full clarity, it should be referred to the total amount of fuel consumed, or mileage traveled, as then it will only be possible to find out what it results from.

2. Remuneration (of drivers) increased by $12.9 \%$ (+42.2 thousand PLN). Unfortunately, no data were available to indicate the cause of the phenomenon, and it could be both wage growth as well as an increase in the number of hours worked, and the combined effect of both factors. 
3. The costs of buying spare parts and oils increased by $12.5 \%(+20.0$ thousand PLN). This growth rate is higher than the increase in fuel costs, so it is worth looking for a more detailed explanation. If the consumption of spare parts and oils had remained proportionate to the costs of purchasing fuel, then this increase would have been due to a faster increase in the price of these assortments, but does not have to be the case.

4. What is interesting is the reduction of costs of road charges by $13.0 \%$. $(-19,200$ thousand PLN). It cannot result from the reduction in mileage as this increased, so the reason may be the increased use of unpaid routes.

5. The paid tax on transport means slightly increased, by $6.6 \%(+2.2$ thousand PLN), which probably results from the increase of its rates.

6. The remaining components i.e. vehicle insurance costs and leasing fees remain unchanged (at a level of 1-2\%).

7. Changes in the costs structure are also visible. The share of core operating expenses increased by $2.8 \%$. In this group, the most significant increase was in fuel costs $-1.9 \%$ and salaries $-1.1 \%$, as well as purchases of oils and spare parts. The costs of road tolls $(-0.5 \%)$.

Operating costs of other activities:

- absolute deviation (25):

$\Delta K_{\text {other operating }}=K_{\text {other operating }(2015)}-K_{\text {other operating }(2014)}=$ 476,0 [thousand PLN] - 552,3 [thousand PLN] $=-76,3$ [thousand PLN]

- dynamics indicator (26):

$W_{\text {Kother operating }}=\frac{K_{\text {other operating }(2015)}}{K_{\text {other operating. }(2014)}} \cdot 100 \%=\frac{476,0[\text { thousand } P L N]}{523,3[\text { thousand } P L N]} \cdot 100 \%=86,2 \%$

In the area of operating costs of the remaining business:

tire purchase costs:

- absolute deviation (27):

$$
\begin{aligned}
& \Delta K_{\text {tires }}=K_{\text {tires(2015) }}-K_{\text {tires (2014) }}=200,0[\text { thousand PLN] }- \\
& 250,0[\text { thousand PLN] }=-50,0[\text { thousand } P L N]
\end{aligned}
$$

- dynamics indicator (28):

$$
W_{\text {Ktires }}=\frac{K_{\text {tires }(2015)}}{K_{\text {tires }(2014)}} \cdot 100 \%=\frac{200,0[\text { thousand } P L N]}{250,0[\text { thousand } P L N]} \cdot 100 \%=80,0 \%
$$

workshop costs:

- absolute deviation (29):

$$
\Delta K_{\text {workshop }}=K_{\text {workshop(2015) }}-K_{\text {workshop (2014) }}=149,6[\text { thousand PLN] }-
$$

162,7 [thousand PLN] $=-13,7$ [thousand PLN]

- dynamics indicator (30):

$$
W_{K f u e l}=\frac{K_{\text {workshop }(2015)}}{K_{\text {workshop }(2014)}} \cdot 100 \%=\frac{149,6[\text { thousand } P L N]}{162,7[\text { thousand } P L N]} \cdot 100 \%=91,9 \%
$$

\section{Results and discussion:}

1. The share of other operating costs decreased by $2.3 \%$, which was mainly due to purchase of tires $(-1.5 \%)$ as well as workshop costs $(-0.4 \%)$. The share of office costs also decreased by $0.4 \%$, but its impact on the entire cost category is much weaker, due to the much smaller share of this cost category. The other components do not show any significant changes, and their impact on the whole category is small.

2. Within the costs category, some structural changes are also visible. In particular, the biggest changes concern: 
a) In the area of operating costs of core business, the share of wages increased by $0.9 \%$ and the purchase of parts and oils increased by $0.4 \%$ while the share of road tolls ($0.8 \%)$ and leasing fees $(-0.4 \%)$.

b) In the area of other operating costs, the share of workshop costs increases $(+2.0 \%)$, energy $(+1.1 \%)$ and delegations $(+1.0 \%)$. On the other hand, the share of tire purchase costs $(-3.2 \%)$ and office costs $(-1.2 \%$ has significantly decreased \%).

As for financial costs:

- absolute deviation (31):

$\Delta K_{\text {financial }}=K_{\text {financial(2015) }}-K_{\text {financial (2014) }}=11,7[$ thousand PLN] 30,7 [thousand PLN] $=-19,0$ [thousand PLN]

- dynamics indicator (32):

$$
W_{K \text { financial of fuel }}=\frac{K_{\text {financial }(2015)}}{K_{\text {financial }(2014)}} \cdot 100 \%=\frac{11,7[\text { thousand } P L N]}{30,7[\text { thousand } P L N]} \cdot 100 \%=38,1 \%
$$

\section{Results and discussion:}

The of financial costs has decreased significantly by $0.5 \%$, but due to their small share of total costs the impact of this factor on the result is small. In 2015, in comparison with 2014, the company's revenues decreased (table 4). The detailed analysis showed that this was primarily due to a decrease in the number of completed transport orders and a decrease in the price obtained on a single transport order. The total costs in 2015 slightly increased in comparison with 2014. The main reason for the increase in costs is the increase in prices of fuel, salaries, oil and spare parts. A detailed analysis showed that the transport company was able to reduce the impact of these factors on the final result by reducing costs in other business areas.

Table 4: A summary of the results of the detailed analysis of the examined transport company

\begin{tabular}{|c|c|c|c|c|c|}
\hline & & \multicolumn{2}{|c|}{$\begin{array}{l}\text { YEAR } \\
\text { [thousand PLN] }\end{array}$} & \multirow{2}{*}{$\begin{array}{l}\text { Absolute } \\
\text { deviation [tys. zł] } \\
2015-2014\end{array}$} & \multirow{2}{*}{$\begin{array}{l}\text { Dynamics } \\
\text { indicator [\%] } \\
2015 / 2014\end{array}$} \\
\hline & & 2014 & 2015 & & \\
\hline \multicolumn{2}{|c|}{ TOTAL COSTS } & 3517,4 & 3544,3 & 26,9 & 100,76477 \\
\hline \multirow{9}{*}{1} & Basic operating costs & 2934,4 & 3056,6 & 122,2 & 104,2 \\
\hline & a Purchase of fuel & 1867,7 & 1950,0 & 82,3 & 104,4 \\
\hline & b Remuneration & 328,0 & 370,2 & 42,2 & 112,9 \\
\hline & c Phone costs & 16,0 & 12,6 & $-3,4$ & 78,8 \\
\hline & d Purchase of spare parts, oils & 160,0 & 180,0 & 20,0 & 112,5 \\
\hline & e Vehicle insurance & 90,6 & 89,5 & $-1,1$ & 98,8 \\
\hline & f Tax on transport means & 33,2 & 35,4 & 2,2 & 106,6 \\
\hline & g Tolls & 147,2 & 128,0 & $-19,2$ & 87,0 \\
\hline & $\mathrm{h}$ Leasing costs & 291,7 & 290,9 & $-0,8$ & 99,7 \\
\hline \multirow[t]{10}{*}{2} & Other operating costs & 552,3 & 476,0 & $-76,3$ & 86,2 \\
\hline & a Workshop costs & 162,7 & 149,6 & $-13,1$ & 91,9 \\
\hline & b Correspondence costs & 8,3 & 5,2 & $-3,1$ & 62,7 \\
\hline & c Office costs & 54,0 & 40,6 & $-13,4$ & 75,2 \\
\hline & d Energy costs & 24,0 & 25,7 & 1,7 & 107,1 \\
\hline & e Purchase of tires & 250,0 & 200,0 & $-\mathbf{5 0 , 0}$ & 80,0 \\
\hline & f Technical research of vehicles & 3,6 & 3,3 & $-0,3$ & 91,7 \\
\hline & g Telephone costs & 12,0 & 11,9 & $-0,1$ & 99,2 \\
\hline & h Property tax & 13,7 & 14,2 & 0,5 & 103,6 \\
\hline & i Delegation costs & 24,0 & 25,5 & 1,5 & 106,3 \\
\hline & Financial costs & 30,7 & 11,7 & $-19,0$ & 38,1 \\
\hline & a Bank charges & 30,7 & 11,7 & $-19,0$ & 38,1 \\
\hline & Extraordinary costs & $\mathbf{0 , 0}$ & $\mathbf{0 , 0}$ & $\mathbf{0 , 0}$ & - \\
\hline & a Extraordinary costs & 0,0 & 0,0 & $\mathbf{0 , 0}$ & - \\
\hline
\end{tabular}

Source: Own elaboration based on the conducted research 
At this stage of the analysis, the general conclusion of the analysis can be formulated as follows: the transport company encounters difficulties in its operation and works well with them maintaining a positive financial result.

\section{Conclusion}

The structure and behavior of its costs has a decisive meaning for achieving the objectives of the transport company. That is why it is so important to constantly observe costs that allow to undertake the right actions at the right time. The research conducted by the authors regarding revenue and costs analysis lead to the unequivocal conclusion that running a business as a transport company is not easy, as it is constantly changing and also forces entrepreneurs to be flexible, creative and devoted to valuable information influencing business development. The fact is that the key to success is taking proper decisions by those managing in the company with regard to capital management. Thus, the quintessence of longterm operation of the company on the European market results primarily from the maximization of benefits, which is synonymous with increasing the value of the enterprise. The effect of such activities is the permanent pursuit to extending the profile of activity, sales markets as well as searching for new development opportunities. In order to succeed, it is necessary to determine the capital needed to finance the investment while maintaining the continuity of ongoing economic processes. It results that investment and financing are interrelated in both the planning and strategic decision making processes of a transport company.

\section{References}

Bąk, M. (2009). Koszty i opłaty w transporcie. Wyd. Uniwersytetu Gdańskiego, Gdańsk.

Bien, W. (2002). Zarządzanie finansami przedsiębiorstwa, Difin. Warszawa.

Bachmann, Ch., Roorda, M.J. \& Kennedy, Ch. (2016). Global trade creation, trade diversion, and economic impacts from changing global transport costs. Transportation Research Record, 2598, 46-57.

Bagloee, S.A., Sarvi, M. \& Ceder, A. (2017). Transit priority lanes in the congested road networks. Public Transport, 9(3), 571-599.

Friedrich, R. \& Quinet, E. (2011). External costs of transport in Europe. Handbook of Transport Economics, 369-395.

Greene, D.L., Jones, D.W. \& Delucchi, M.A. (1997). The full costs and benefits of transportation. Springer Verleg, Berlin-Heidelberg.

Grad, B., Ferensztajn-Grad, E. \& Krajewska, R. (2012). Aspekty efektywności ekologicznej systemów transportowych Unii Europejskiej. Drogi: Budownictwo Infrastrukturalne, 42-51.

Hensher, D. and Button, K. (2005). Handbook of transport modelling. Handbooks in Transport. PergamonElsevier Science, Amsterdam.

Hanssen, T.-E. S., Mathisen, T. A. \& Jorgensen, F. (2012). Generalized transport costs in intermodal freight transport. $15^{\text {th }}$ Meeting of the Euro-Working-Group-on-Transportation (EWGT). Paris, FRANCE.

Jacyna, M. \& Pyza, D. (2015). Rola intermodalnych terminali przeładunkowych w przewozach kolejowodrogowych. Problemy Kolejnictwa, 169, 15-27.

Kovacs, G. (2017). First cost calculation methods for road freight transport activity. Transport and Telecommunication, 18(2), 107-117.

Kozlak, A. (2008). Ekonomika transportu. Teoria i Praktyka Gospodarcza. Wyd. Uniwersytetu Gdańskiego, Gdańsk.

Kovacs, G. \& Guban, M. (2017). Planning of optimal fuel supply of international transport activity. Periodica Polytechnica Transportation Engineering, 45(4), 186-195.

Krysiuk, C., Brdulak, J. \& Zakrzewski, B. (2014). Bezpieczna infrastruktura w transporcie drogowym. Logistyka, 4. 
Kusminska-Fijałkowska, A., Łukasik, Z. \& Kozyra, J. (2017). Noise in road transport as a problem in European dimension. In safety of sea transportation. 12th International Conference on Marine Navigation and Safety of Sea Transportation. Gdynia, Poland, 141-148.

Kusminska-Fijalkowska, A. \& Lukasik, Z. (2011). The land trans-shipping terminal in processes flow stream individual's intermodal transportation. Transport Systems and Processes: Marine Navigation and Safety of Sea Transportation, 13-18.

Kibzun, A. I. \& Khromova, O. M. (2016). Mathematical modeling of a transport system with minimal maintenance costs. Bulletin of the South Ural State University, Mathematical Modeling Programming \& Computer Software, 9(3), 41-54.

Leszczynski, Z. \& Skowronek-Mielczarek, A. (2001). Analiza ekonomiczno-finansowa firmy. Difin, Warszawa.

Łukasik, Z. \& Olszanska, S. (2016). Kształtowanie kosztów międzynarodowej obsługi transportowej w systemie Just-In-Time. Autobusy, 6, 643-646.

Łukasik, Z., Kusminska-Fijałkowska, A. \& Kozyra, J. (2017). Transport of dangerous goods by road from a European aspect. Scientific Journal of Silesian University of Technology, 95.

Łukasik, Z., Bril, J. \& Bril, D. (2013). Zagrożenia związane z transportem drogowym. Autobusy: Technika, Eksploatacja, Systemy Transportowe, 14, 45-57.

Łukasik, Z. et al. (2017). Shaping the cost of transport on the example of the transport company. Proceedings of 21 st International Scientific Conference Transport Means. Kaunas, Lithuania, 128-136.

Łukasik, Z., Kusminska-Fijałkowska, A. \& Kozyra, J. (2017). Industrial noise in measurement and statistical terms in Poland. 2nd International Conference on Advanced Materials Science and Environment Engineering.

Lukasik, Z., et al. (2017). A case study of noise coming from road transport to people and the environment. Proceedings of 21 st International Scientific Conference Transport Means 2017. Kaunas, Lithuania, 325-334.

Maibach, M., et al. (2008). Handbook on estimation of external costs in the transport sector. CE Delft.

Mostert, M., Caris, A. \& Limbourg, S. (2017). Road and intermodal transport performance: the impact of operational costs and air pollution external costs. Research in Transportation Business and Management, 23, $75-85$.

Monzon, A., Fernandez, A. \& Jorda, P. (2008). Environmental costs account: A base for measuring sustainability in transport plans. 9th Highway and Urban Environment Symposium (9HUES), Univ Politecn Madrid, Spain.

Nowacki, G., Krysiuk, C. \& Kopczewski, R. (2016). Dangerous goods transport problems in the European Union and Poland. TransNav: International Journal on Marine Navigation and Safety of Sea Transportation, 10(1), 143-150.

Nowacki, G., Krysiuk, C. \& Niedzicka, A. (2015). Selected transport problems of dangerous goods in the European Union and Poland. Safety of Marine Transport: Marine Navigation and Safety of Sea Transportation, 297.

Nowakowski W., Łukasik Z. \& Bojarczak, P. (2006). Technical safety in the process of globalization. Proceedings of the 16th International Scientific Conference Globalization and Its Socio-Economic Consequences. Rajecke Teplice, Slovakia, 1571-1578.

Nowacki, G., Krysiuk, C. \& Kopczewski, R. (2016). Dangerous Goods Transport Problems in the European Union and Poland. TransNav: International Journal On Marine Navigation and Safety of Sea Transportation, 10(1), 143-150.

Ozceylan, E. (2010). A decision support system to compare the transportation modes in logistics. International Journal of Lean Thinking, 1(1).

Petruccelli, U. \& Carleo, S. (2017). Cost models for local road transit. Public Transport, 9(3), 527-548.

Pregnolato, M. et al. (2017). Impact of climate change on disruption to Urban transport networks from pluvial flooding Journal of Infrastructure Systems, 23(4).

Twarog, J. (2003). Koszty logistyczne przedsiębiorstw. ILiM, Poznań.

Takeshita, T. (2010). Cost-optimal technology and fuel choices in the transport sector under a stringent climate stabilization target. Climate Change and Variability, 439-461.

Umberto, P. (2015). Assessment of external costs for transport project evaluation: Guidelines in some European countries. Environmental Impact Assessment Review, 54, 61-71.

Yanxuan, L. \& Wayuparb, A. (2016). Impacts of backhauls on freight transport cost. A review of literature. $3^{\text {rd }}$ International Conference on Management Innovation and Business Innovation (ICMIBI 2016). Book Series: Lecture Notes in Management Science. Manila, Philippines, 58, 249-259. 